\title{
Sacrifice/Human Sacrifice in Religious Traditions
}

\section{Citation}

Carrasco, David. 2013. Sacrifice/Human Sacrifice in Religious Traditions." In The Oxford Handbook of Religion and Violence, eds. Mark Juergensmeyer, Margo Kitts, and Michael Jerryson, 209-235. Oxford and New York: Oxford University Press, 2013.

\section{Published Version}

doi:10.1093/oxfordhb/9780199759996.013.0011

\section{Permanent link}

http://nrs.harvard.edu/urn-3:HUL.InstRepos:34814073

\section{Terms of Use}

This article was downloaded from Harvard University's DASH repository, and is made available under the terms and conditions applicable to Other Posted Material, as set forth at http:// nrs.harvard.edu/urn-3:HUL.InstRepos:dash.current.terms-of-use\#LAA

\section{Share Your Story}

The Harvard community has made this article openly available.

Please share how this access benefits you. Submit a story.

Accessibility 
THE OXFORD HANDBOOK OF

\section{RELIGION AND VIOLENCE}

Edited by

MARK JUERGENSMEYER,

MARGO KITTS,

and

MICHAEL JERRYSON 


\section{OXFORD}

Oxford University Press is a department of the University of Oxford. It furthers the University's objective of excellence in research, scholarship, and education by publishing worldwide.

$$
\text { Oxford New York }
$$

uckland Cape Town Dar es Salaam Hong Kong Karachi Kuala Lempen Madrid Melbourne Mexico City Nairobi New Delhi Shanghai Taipei Toronto

With offices in

Argentina Austria Brazil Chile Czech Republic France Greece Guatemala Fungary Italy Japan Poiand Portugal Singapore

Oxford is a registered trademark of Oxford University Press in the UK and certain other countries.

Published in the United States of Americal by Oxford University Press 198 Madison Avenue, New York, NY 10016

\section{(c) Oxford University Press 2013}

All rights reserved. No part of this publication may be reproduced, stored in a retrieval system, or transmitted, in any form or by any means, without the prior permission in writing of Oxford University Press, or as expressly permitted by law, by license, or under terms igreed with the appropriate reproduction rights organization. Inquiries concerning reproduction outside the scope of the above should be sent to the Rights Department, Oxford University Press, at the address above.

You must not circulate this work in any other form

on any accuirer.

Library of Congress Cataloging-in-Publication Data

The Oxford handbook of religion and violence / edited by Mark Juergensmeyer, Margo Kitts, and

$$
\text { Michael Jerryson. }
$$

$$
\begin{gathered}
\text { p. cm. } \\
\text { Includes index. }
\end{gathered}
$$

ISBN 978-0-19-975999-6 (hardcover : alk. paper) 1. Violence-Religious aspects.

I. Juergensmeyer, Mark. II. Kitts, Margo, 1952- III. Jerryson, Michael K.

IV. Title: Handbook of religion and violence.

$$
\begin{gathered}
\text { BL.65. } 555 \mathrm{O} 942013 \\
201.76332-\mathrm{dc23} \\
2012012032
\end{gathered}
$$

ISBN 978-0-19-975999-6 
CHAPTER 11

\title{
SACRIFICE/HUMAN SACRIFICE IN RELIGIOUS TRADITIONS
}

\author{
DAVÍD CARRASCO
}

WHEN the archaeologist Saburo Sugiyama opened up a chamber in the center of the Pyramid of the Feathered Serpent at Teotihuacan, Mexico, he found a collection of eighteen male human bodies crowded together wearing greenstone nose pendants, earplugs, and beads. All had been sacrificed and appear to have been high status adults. Further excavating the pyramid, Sugiyama's team discovered human sacrificial burials along the four borders of the elaborately sculpted ceremonial precinct (Sugiyama 2005). Some wore necklaces of small shell beads while others had the unusual adornment of collars with human maxilla (upper human jaw) pendants. Back disks and abundant projectile points appeared in some burials as well as a number of females who had been sacrificed and wore shell earplugs and cylindrical shell beads. The surprising discovery began a reformation in our understanding of the ritual life and political worldview of the great capital that for decades had been viewed as the center of a "Pax Teotihuacana." Previously it was thought that this imperial city ruled large numbers of people and territories through a theocratic system of persuasion and intimidation with little need of practicing human sacrifice. Further studies of these ruins and the sites and inscriptions of the great Classic Maya civilization in southern Mesoamerica have transformed our understanding of how thoroughly ritual violence toward human beings and human sacrifice, in particular, created and maintained social order while also serving as instruments of communication about cosmology and moral life (López Luján and Olivier 2010). We now know that human sacrifice is embedded in the social, pictorial, and literary record of Mesoamerica, which presents a challenge to interpreters of not only this cultural area but of our understanding of religion and violence more broadly. 
Spurred by these discoveries in Mesoamerica, scholars have asked about the uniqueness of the forms of Aztec and Maya human sacrifices in world religions (Lopez Austin and López Luján 2008). In a surprise to some, it turns out that many societies previously lauded for their sophisticated philosophies, magnificent building programs, and the "rise of civilization" carried out human sacrifices and massacres to their gods as part of their performative traditions, ethical justifications, and political philosophies. This widespread threading of human sacrifice within the urban societies of Mesoamerica and elsewhere justify following the lead of Walter Burkert who, even as he was focusing on animal sacrifices in Greece, wrote that " $[\mathrm{m}]$ ore can be said for the thesis that all orders and forms of authority in human society are founded upon institutionalized violence" (Burkert 1986).

This chapter begins with a survey of several contemporary, major definitions of sacrifice as forms of symbolic and performative violence. Following a modest discussion of patterns in the sacrifices of animals and their symbols in various traditions, the chapter turns to an interpretation of the more troubling topic of actual human sacrifices in various cultures with special attention to the best-documented traditions of Mesoamerica. Given the abundance of textual and archaeological evidence for a wide range of types and purposes of these ritual killings in public places, I choose to focus on two analogies and patterns of performative violence: human sacrifice as warfare, such as the human sacrifices that made the Aztec capital into the ideal battlefield, and human sacrifice as a moral imperative for the warrior. Even when a sacrifice of a woman is designed to produce agricultural renewal, its symbolism and the use of the body are redirected, in part, by the male warrior ideal. The ritual killing of human beings, in Mesoamerica at least, is often a public performance designed to communicate and persuade the populace that commitments to cosmic warfare, debt payments to the gods, and correct gender relations are being carried out to maintain the social and cosmic order. These human sacrifices are, in the words of Jon Levenson writing about child sacrifices in Judaism and Christianity, "extreme acts of devotion" (1995: 17) and also instruments in a cosmological conviction carried out by ritual specialists in order to make the city and society at large endure. Looking at the Mesoamerican cases will help us reflect on the broader claim made by one scholar, concerned about whether the origin of violence in human beings is to be located in biology or culture. He writes: "The one thing that cannot be denied is that violence is ubiquitous and tenacious and must be accounted for if we are to understand humanity" (Hamerton-Kelly 1987: vi).

\section{SACRIfice AND ReBOUNDING VIOLENCE}

Sacrifice comes from Latin sacrificium (sacer, "holy"; facere, "to make") denoting the act of killing an animal or person as an offering to a deity. Sacrifices are extraordinary processes involving dramatic communications leading to social and ontological changes (Henninger 2005). Its common usage today extends to such acts as giving up a valued object or status for a greater cause or good such as sacrificing a pawn in chess for tactical gain or a sacrifice bunt in baseball. But its more durable and powerful meaning of killing as a form of communication with a deity, gift giving, or expiation to a higher being points to its long association with performative violence.

According to scholars such as Henninger, a wide range of objects including animals, plants, stones, and human-made items are used in sacrifices in various traditions. Of special importance is that the performance of sacrifices, of whatever material, establishes or rejuvenates intimate relationships with supernatural beings considered crucial to a community's well-being. While there is disagreement over the definition of violence (see Das, chapter 1 in this volume) and the term sacrifice suffers from an instability of meaning, we can work with the following pattern of sacrificial rituals to explore similarities between distinct religious traditions. I call this pattern a performative scenario of sacrifice, which includes a) the forceful setting apart of a valued object (elevated or debased) b) in a liminal space where supernatural and social realms meet in a c) performance of cosmic significance d) focused by the symbolic and/or material injury or destruction of a creature representing a "life force" e) meant to sustain or rejuvenate what is valued as a greater life force or to bring about a social benefit to a community in need of supernatural power. In a performative scenario or public ceremonial sequence of events meant to develop intimate exchanges between humans and supernatural beings, relationships between cosmic levels are mediated through dramatic and symbolic gestures aimed at stimulating the human senses of sight, sound, smell, and often taste so as to make humans internalize the experience and meaning of sacrifice. In some religious traditions, there are myths that say the gods performed sacrifices of themselves in order to initiate life in the cosmos.

While it may be thought that bloodless offerings lack violence, Maurice Bloch's revealing work titled Prey into Hunter shows that "the irreducible core of ritual practice" organized two types of violence at work in New Guinea and elsewhere. Even when killings are only alluded to or remembered, this practice is marked by a violent separation of people, animals, and objects from domesticated spaces. This separation is followed by ritual acts that bring about a radical change in the vitality of the separated entities (actual and symbolic) within a sacred location. The final phase involves the return of these revitalized beings to the social order through a form of "rebounding violence." Humans create this two-way movement out of the awareness of a profound and deeply felt paradox. On the one hand, they are transient beings who live, die, and disappear. On the other hand they dwell "within a permanent framework which transcends the natural transformative process of birth, growth, reproduction, aging and death." The result is the invention of rituals that symbolically deny the transience of life and participate in a transcendent reality where spirits, gods, and ancestors live forever. The goal of these sacrifices and initiations is to acquire a long lasting "religious vitality" and bring it back into the community through specific kinds of actual and symbolic violence. These dramatic forms of violence strive in many traditions to acquire cosmomagical powers that Bloch refers to as "plundered vitality." In the case of the Orokovia children who 
are identified with vulnerable pigs (that are normally killed and eaten by humans) they are separated from their parents and village so they can be cosmomagically mixed with the "realm of spirits or gods" where they acquire a new kind of vitality, a spirit vitality. It is only after this supernatural change that the former prey, who is now a child-spirit combination, can descend back into the community as a potential hunter-warrior. This return requires a rebounding violence that brings back to the family and society the revered spirit powers of the spirit-dead that are immortal and transcendent. This sequence of two violences subsequently allows human children to legitimately express aggression toward humans and animals that they can now hunt and kill. Bloch believes this is the matrix that underlies many sacrifices and also gives power and wisdom to people.

A similar motive for sacrifice is found in a deep tradition of Indian thought and ritual, according to J. C. Heesterman in The Broken World of Sacrifice (1993). Human beings faced with the riddle of life and death, such as the awareness that each of these profound realities is intimately linked to its opposite, explored an answer to the riddle through sacrifices of various kinds. In the Indian case, preVedic rituals were animated by conflict and contest and included three stages: killing, the ritual destruction of the sacrificed object, and its distribution in a ritual meal. Symbolic violence and physical violence were woven closely together in the search for a resolution to the puzzle. In Heesterman's view human sacrifice was, after a long period of application to the puzzle, deemed unsatisfactory for the Indian communities that eventually broke the world of sacrifice and created new ritual strategies filled with substitutes for human killing.

The crucial role of emotion and aggression in sacrifice appears in a number of Greek rituals and cultural expressions such as oracles, games, mysteries, dramas, and funeral and royal ceremonies. Apparently modeled on human-animal relations as expressed in the Paleolithic hunt and the shared sacrificial meal, the handling of animal bones signals feelings and thoughts of intimacy among humans and between humans and animals (Burkert 1986). The hunt was a supremely collective, dramatic experience that demanded not only knowledge of disciplined movement and behavior in the outdoor pursuit of game, but also the skillful handling of unwieldy human aggressions-often felt toward other humans-by refocusing them onto the animal prey that became the sacrificial victim. In Burkert's view, the dramatic scenes and emotions associated with the killing of animals after careful planning and intense physical and mental exertions resulted in new cultural processes of perception and reflection, including the telling of stories and the creation of mythologies about the events. In a formulation that assists our efforts to fathom the patterns of human sacrifice, Burton Mack summarizes well Walter Burkert's achievement in linking the hunt and sacrifice of animals to a profound understanding of religion when he summarizes:

[T] he hunting ritual gave rise to the full range of articulations that we understand to be mythic or symbolic, articulations characteristic of religion. The naming of the "Master of the Animals", the songs and "prayers" that address the prey, the gestures surrounding the kill, the care of the bones, the narration of the ritualized. hunt as a sequence of events (myth), and the eventual articulation of social codes and honors, including honors due the Master of the Animals ("worship") all are found to be generated by the complex experience of the act of killing. Thus a theory of the ritualization of the hunt becomes a theory of the origin of religion. (Burton Mack 1987: 26)

In this theory of religion and sacrifice, the effectiveness and emotionality of the kill as well as its intense planning and coordination are not only the dramatization of a new social ordering, it actually restructures society for the satisfaction of basic human needs. We are then led to ask if the same kind of social achievement and source of new religious sensibility can be assigned to the ritualization of human killing?

Much of the literature on human sacrifice in religions of the world speaks of either a transformation or evolution of human sacrifices into animal sacrifices or substitutions of animals or other objects for human kind. In the words of another scholar writing in this volume about violence and nonviolence in the Vedas, we see the pattern of "ritual substitution that keeps the symbolic presence of violence very much in the picture without actually committing the acts of killing" (Das 2012). Jon Levenson's excellent study of child sacrifices in Judaism and Christianity shows how even when the practice of human sacrifice was eradicated, the religious idea of child sacrifice remained "potent and productive." He celebrates this transformation "as highly positive, one that metamorphosized a barbaric ritual into a sublime paradigm of the religious life" (1995: $x$ ). What, then, do we say of the humanity and ritual practices of many human communities including those of some Native Americans who in many locations and eras continued to carry out the ritual destruction of human beings even while they were sacrificing animals and creating cities, great art, complex calendar and writing systems, and sophisticated philosophies and theological systems. More than one Spanish priest noted, even while they condemned the sacrifices of the Maya and Aztecs, that they had never been in societies in Europe where people cared as much for their children and families as the Mesoamericans. When we get to the many Mesoamerican examples of ritual violence toward human beings we find another kind of "substitution" at work. It is the gods who were "substituted" for humans, and the human sacrificial object was ritually emptied of human identity and filled with the living spirits of the divinity who was, in the theological twists and turns of various cultures, the entity that was now beheaded, followed by a heart extraction and sometimes immolation. The result in this theological system was a new birth for the god who had just been destroyed, reappearing in vital substances of plants, animals, stars, and even the kings. Before turning to the performative scenarios of these Mesoamerican human sacrifices, a short tour of human sacrifice elsewhere will set the backdrop.

\section{Human SACRifices Elsewhere}

Human sacrifice in many parts of the world fit into a broader set of sacrificial practices that include the intentional disposal of animal parts, animals, and highly valued objects (including bronzes and jades in China, ceramics and paper in 
Mesoamerica, and other materials), with roots that extend back into the Neolithic and Paleolithic periods. Among the human objects sought in sacrifice were human heads. Headhunting for religious purposes appears in many parts of history around the globe including among the Scythians as reported by Herodotus who tells that they hung the heads of enemies around the neck of their horses to display their accomplishments. The Celts in Ireland, the Iroquois in the United States and the Dayak of Borneo also killed humans for the purpose of gathering heads and gaining supernatural power. In sensational performative acts, Saiva ascetics ate from human skulls and meditated on cadavers. Headhunting has more recently received illuminating attention in a series of studies showing and debating the meanings of the practice of taking heads and the ceremonial remembering of headhunting in the Philippines and elsewhere (Rosaldo 1980; George 1996).

Human sacrifices were also carried out to restore authority and rejuvenate the well-being of towns and cities. According to Robert Turcan, the Athenians purified their polis with the sacrifice of two humans called pharmakoi-one representing the guilt of all Athenian men and the other carrying the guilt of all the women in the city. More to the point, human sacrifices often occurred in the ritual cult around kings and social elites whose potency in this world and destiny in the next required the killing of other humans. Examples include, in Africa, the former requirement that the Rukuba king's installation ceremony included him ingesting small pieces of two different human beings, his deceased predecessor and an infant killed for this propitious event and thereby insuring the longevity of his reign. The tie between human sacrifice and the palaces of royal families was expressed in the Abomey where the king's house was built over the entrails of a conquered enemy chief. Sacrifices became the very stuff of the buildings as when human blood from ritual killings was mixed with the earthen materials used to build the palace walls (Monroe 2007).

The link between sacrifice, elites, and warfare is abundantly shown in periods of Chinese history. The scale of sacrificial activity grows tremendously in the Early Bronze Age, to an extent that states in China are famously said to have been founded and maintained on a basis of "sacrifice and warfare" (according to the Zuozhuan, a chronicle of the Springs and Autumns period [770-481 BCE] that was compiled during the subsequent Warring States period [480-221 BCE]). Sacrifices of humans are related to traditions of ancestor worship that have Neolithic roots (Liu 2000) and, ultimately, to practices that legitimated the hegemony of the state. It was during the Shang period that we have the first extensive evidence of large-scale human sacrifices, and scholars have postulated three broad types of human sacrifices that have considerable overlap (Campbell 2007: 177; Fiskesjö 2003: 60-61). The first are foundation sacrifices, which were those used as dedicatory offerings in the context of construction events of special buildings. These typically comprise human remains (and other offerings) found in pits in or under foundations of important buildings. The second are sacrifices to spirits or ancestors, typically found in individual pits otherwise associated with rammed earth (i.e., elite) structures or elaborate burials. The third type of human sacrifice has been designated as death attendants, typically considered to be members of the been design on entourage of elites who were interred in tombs. In some cases, a kind households or entourage of elites who were interred in the fom the dite burials, such as shallow pits called waist pits beneath the main occupant's chamber. Humans buried with horses and chariots in separate sacrificial pits are included in this broad category of sacrificial victims. Among the most famous included in there these different sorts of human sacrifice can be distinguished is the royal cemetery at Xibeigang. Located northwest of Yinxu, the last capital of the Shang Dynasty, Xibeigang contained nine huge cruciform-shaped tombs attributed to the Shang kings and several other large tombs with one or two entry ramps (also considered royal tombs). These large tombs were surrounded by thousands of small graves and sacrificial pits, and human sacrifices have been found in the large tombs as well (Chang 1980: 110-123).

\section{SELF-SACRIFICE}

Human destruction is also turned toward the self in a number of traditions. It is a surprise to many to learn that the most common form of sacrifice among the Aztecs and Maya was self-sacrifice in many forms of bloodletting, a practice that started during infancy when parents drew blood from children during special calendar rituals (Klein 1987). More dramatic self-sacrifice appeared in the Hindu practice of sati with the self-immolation of widows (sometimes forced, sometimes voluntary) on their husband's funeral pyre (Geertz 1981). It is believed that the widow is only half alive and, at least during the Brahmanical period, she faced three choices: remarry the younger brother of her husband, a lifetime commitment to servitude in a widow's ashram, or sati. These "voluntary" sacrifices are justified by the cosmological belief that two human bodies are united in the fire to make one indivisible body (Weinberg-Thompson), thus enabling the couple to escape the cycle of birth-death and rebirth.

A form of self-sacrifice continues today in Japan where suicides in various forms are carried out under the influence of Confucian concepts of honor and in the shadow of the rubric of samurai who were compelled to commit seppuku for any number of reasons, including atonement for transgressions or to complete a code of honor. The classic case of self-sacrifice through ritual disembowelment is known as the Forty-Seven Ronin, in which a group of samurai was forced by the government to commit seppuku in punishment for murdering a high official. This event has become extremely popular in Japanese art and theater because it represents the ideal of how one should live a life of honor, loyalty, and commitment to authority. It is evident that kamikaze pilots toward the end of World War II followed this tradition with their suicide attacks on naval vessels thereby following the code of death instead of defeat or shame. 
A huge, one-time example of group self-sacrifice or "revolutionary suicide": occurred in Jonestown, Guyana, in 1978 when nearly 909 people were persuaded to drink cyanide poison by their charismatic leader James Jones, who instead shot himself to death. It was the greatest single loss of life of American civilian life in a non-natural event until the attacks on $9 / 11$.

\section{The Cities of Sacrifice}

A recent, comprehensive volume with twenty-four essays El sacrificio humano en la tradición religiosa mesoamericana (López Luján and Olivier 2010) opens new challenges for understanding not only the technique and performances of human sacrifice in Mesoamerica but also for scholars attempting new theories about religion and violence. It is something of a scandal in religious studies and anthropology, which the present publication attempts to address, that all significant theories of ritual sacrifice, from Robertson Smith through Henri Hubert and Mauss, Wilhelm Schmidt, Alfred Jensen, René Girard, Walter Burkert, J. Z. Smith, and Robert Hamerton-Kelley ignored, with minor exceptions, the most fulsome record of real, historical human sacrifices from Mesoamerica while instead favoring animal sacrifice or literary accounts of human sacrifices from Western classics to form their interpretations.

I can identify with the urge to turn our thinking heads away from this record because it challenges so much of what we say and hope to find in the history of human violence. I remember when my own academic deadpan, confident as a stone mask, cracked in the face of an offering cache at the Great Aztec Temple filled with the skeletal remains of forty-two children. I was the father of a young child and here before me was a ritual chamber filled with children's skulls and infant bones strewn and tangled in a chaotic and wild looking arrangement. I could see traces of green stone beads near several mouths, flakes of blue pigment sprinkled on the bodies, necklaces of greenstone and several disks with appliquéd turquoise mosaics and turtle shell touching the little bodies of these sacrificed children. When I stood up and gazed around at the site with its giant grinning serpent heads, stone warriors leaning against a stairway, and the monumental disk sculpture of a dismembered female warrior, it was evident that public violence against humans was viewed as a profound human necessity and benefit for the Aztecs in their capital city. I wondered, how could we come to understand these not so distant neighbors, in space and time, who played such a dramatic role in the foundations of the Americas when the Europeans arrived and unleashed an even greater violence on local bodies, settlements, and souls? Does it help, I mused, to know that these children were mainly males who were suffering from anemia, parasitism, and gastrointestinal diseases and that sacrifice was thought to alleviate their suffering and make creative, reproductive use of their lives? This event taught me that questions about human sacrifice were much bigger and more complex and grim than I and
a

The Aztec record does not show an evolution away from the sacrifice of the in a human family to a replacement animal. It does not record the "satafirstborn in a human family be sacrificed (Juergensmeyer, "Performance Violence," nization of The people sacrificed in Tenochtitlan were always turned into living chapter 17). The people sacrificed in ter and then led along by male and female ritual gods, the most valued or feared gods, and then led along by male and female ritual specialists on the pathway to the sacrincis. The Aztec name for sacrifice was nextheologize these killings as gift exchanges. The Aztec name for sacrince was nextlaoolli ("the paying of the debt") and the victims were called netlahulaltin ("restitutions") showing that the sacrifices did not emphasize gifts but rather debts (Sahagún 2002: vol. 2). Human children were sacrificed in the first month of every ritual year. Women were sacrificed in a third of the yearly sacrificial ceremonies. The term repeated again and again in the most reliable accounts provided by elders who participated in and witnessed the spectacular ceremonies is debt payment. Debts are a long way from "gifts," though many gifts were exchanged during the paying of debts in the many ceremonial precincts where these performative sceparios were acted out (Carrasco 1999).

Given the abundance of textual and archaeological evidence for a wide range of types and purposes of these ritual killings in public places and the interpretive challenges they present, I now return to the aforementioned two performative scechallenges they present, I now return to the aforementioned two performative scecapital into the ideal battlefield and were instruments of empire, and human sacrifice and moral order, the teaching that the ideal death, the "true" death for the warrior and others, is by sacrifice. A primer on the worldview of human sacrifice will be useful.

\section{The Cosmovision of Human SACRifice}

The evidence for human sacrifice is both obvious and controversial. The archaeological and documentary accounts make it clear that human sacrifice was widely practiced in Mesoamerica for more than 1,500 years and increased in the festivals of the Aztecs and other polities during the Postclassic period between 1100 and 1521 CE. But the Spanish accounts are filled with huge exaggerations, in several cases up to 80,400 victims in a single ceremony, grossly inflated to justify the aggressions, massacres, rapes, and executions carried out by the conquistadores and their entourages.

Regardless of these exaggerations, we now have a grasp on the worldview and cosmovision of human sacrifice in the Aztec Empire. In short form, the Aztecs saw the world as having two distinguishable parts of the universe: the space-time of the gods and the space-time of the creatures of this world that the gods created. 
Human beings, animals, plants, celestial objects, minerals, and rain occupied this visible space-time world that divine beings penetrated into through malinalli, or double-helix-shaped portals located in trees, creeks, caves, and elsewhere. In Aztec mythology, divine beings temporarily departed their space-time and infiltrated everything on Earth giving earthly beings their identities, energies, and powers to live and procreate. All creatures and forces on the earth and in the air were made up of subtle, eternal divine substances and b) hard, heavy, destructible, worldly substances that served as shells to the divine substance. All life-forms on Earth were hard shells covering the divine substance within.

The origin of human sacrifice comes into the story when during various stages of the creation of the world some gods violated divine laws and were expelled from their cosmic region and came to the surface of the Earth. Two cosmic events took place that led to human sacrifice being an imperative for human life. First, to create the cycles of life of the sun and plants on Earth these deities sacrificed themselves in Teotihuacan and descended into the underworld. Now within the Earth, these subtle substances or gods acquired the skins, shells, and other heavy, destructible coverings. Then they reappeared on and above the surface of the earth first as the sun in the sky and then as moon, stars, animals, waters, trees, and so on, and life on Earth was reborn. This journey to the below and back up to the surface of the Earth and the sky became the pattern for earthly creatures who, when they died (or were killed in sacrifice), lost the corporeal covering of their divine substance. Their divine substances went into the underworld waiting for an opportunity to arise again with skins and bodies into the world of humans in the form of new individuals of the same type (López Austin, López Luján 2008). Secondly, the deities eventually grew weary after their sacrifices, descents and reemergence, and required nourishment: "That is why they created the human beings, creatures who were forced to worship them and feed them with offerings and sacrifices. Man perceived himself to be a privileged being because of his close relationship with the gods, but at the same time he was indebted to them because they had created him" (López Austin and López Luján 2008: 145). Human labor and gifts were not sufficient to pay this cosmic debt, and blood offerings and human sacrifice became the solution to this cosmological conviction. The belief was that once a person was ritually transformed into a "god image" and died in sacrifice he or she (the god within the human body) repeated the primordial journey of the gods and traveled to the region of the underworld to recover their strength.

\section{Human Sacrifice, Warfare, and THE IDEAL BATTLEFIELD}

When the Spaniards along with thousands of allied Mesoamerican warriors assaulted the main temples of Tenochtitlan, they saw the huge circular stone altar, where some human sacrifices were carried out in the month of Tlacaxipeualiztli (the Flaying of Men). Spaniards and Mexica warriors fought hand-to-hand combat on and around the stone of sacrifice and when they gained the upper hand, the on and around the stone of sacrifice and when they gained the upper hand, the
Spaniards mounted one of their cannons on it to strengthen their assault on the Great Temple. Years later, when the Franciscan chronicler Bernardino de Sahagún interviewed Aztec elders, they told him the following story, in stunning detail, about a colossal stone altar and a particular nextlaoali or ritual of "debt payment" that came to be known as "the gladiatorial sacrifice."

Captive warriors were transported from enemy territories to the capital of Tenochtitlan where they were paraded through the city before each was ritually transformed into a teotl ixiptla, a living image of the great god Xipe Totec. During the next forty days, these foreign warriors were, step by step, stripped of their culture, human identity, given new names after deities, and forced to dance with their captors but as living representatives of deities. These ixiptla are much more than symbols of deities. López Austin writes of deity impersonators as

teteo imixiptlahuan... men possessed by the gods, who, as such, died in a rite of renewal. The idea of a calendric cycle, of a periodic returning, in which the power of a god was born, grew, decreased, and concluded made it necessary in a rite linking the time of man to mythical time that a god would die so his force might be reborn with new power. It was not men who died, but gods-gods within a corporeal covering that made possible their ritual death on earth. If the gods did not die, their force would diminish in a progressively aging process. Men destined for sacrifice were temporarily converted into receptacles of divine fire, they were treated as gods, and they were made to live as the deity lived in legend. Their existence in the role of ixiptlatin, or "images," could last from a few days up to four years. (López Austin 1988 [italics added])

Some of the ixipylatin were taken to the Great Temple and forced up the steps to the war god, Huitzilopochtli's temple. Some captives resisted or fainted, but some

did not act like a woman; he became strong like a man, he bore himself like a man, he went speaking like a man... he went shouting... he went exalting his city... Already here I go: You will speak of me there in my home land. (Sahagún, vol. 2: 48)

Six offering priests stretched him out on the sacrificial stone, extracted his heart, called "precious eagle-cactus fruit," and offered it to the sun (the text says it "nourished" the sun) before it was placed in the cuauhxicalli or "eagle vessel," a finely carved stone jar or a huge stone receptacle.

This body was cut to pieces and distributed, with one thigh going to the palace for Moctezuma and one piece of flesh eaten by the blood relatives of the captor in a bowl of dried maize stew. Then the victorious captor was decorated with bird down, covered with chalk, and given gifts as well as the names sun, chalk, and feather because he "had not died there in war, or else because he would yet go to die, would go to pay the debt [in war or by sacrifice]."

The second stage of this ritual month began with "the entire city" present at the public spectacle of other captives and their captors in procession to the gladiatorial stone. The procession was led by the elite eagle and ocelot warriors who-amid whistles, singing, and blasts of a conch trumpet-danced, pranced, and displayed 
shields and obsidian-bladed clubs raised in dedication to the sun. Surrounded by a huge crowd of commoners and royal families alike, a captive was made to drink pulque and forced up on the round stone where a priest dressed in bearskin, the "Old Bear," tied his leg with the "sustenance rope" to the center of the stone. Given a war club decked with feathers, the captive was attacked by a dancing jaguar warrior armed with a war club filled with obsidian blades. When the teotl ixiptla was wounded, weakened, and defeated, a figure called the Night Drinker, in the image of the warrior god Xipe Totec, sacrificed the captive, extracting his heart saying, "Thus he giveth the sun to drink." These gestures aimed at linking the city to the celestial realm were followed by the dispersion of the blood along an earthly path as the captor took the eagle bowl filled with the captive's blood to "every place... nowhere did he forget in the calmecacs" where on the lips of the stone images he placed the blood. The body was taken to the local temple school where it was flayed and then taken to the captor's home, where it was cut up for a ritual meal, and those who ate "would be considered gods" (ibid., 2: 67). Then the captor lent the skin to his assistants who begged for gifts for twenty days, after which the gifts were divided among them. This begging ritual, called Neteotoquiliztli, or "the impersonation of a god," involved friends of the captor, now wearing the divine skin of the sacrificed individual, dashing through the streets engaging other youths in little war games, boisterous skirmishes, and mock battles. Part of the game was to try and get a little piece of the skin under one's fingernail so as to acquire a bit of the charisma of the warrior god. Rough-and-tumble fights ensued, eventually calming down so the skin wearers and their entourages could visit family homes where ears of maize were given by the common people and nobles were offered clothes, feathers, and jewels. These war games spread throughout many neighborhoods alerting the populace to the completion of debt payment ceremonies and inviting their involvement in the giving of valued objects to the kids and teenagers.

I left out one crucial detail until now because it reveals the political purpose of this scenario and brutal destruction of human beings. The elders told the Spanish chroniclers that this ceremony, in particular, was attended by foreign rulers and nobles "from cities which were his enemies from beyond (the mountains)...those with which there was war, Moctezuma secretly summoned" to the ceremony and placed behind an arbor of flowers and branches so they would not be seen by the citizens of Tenochtitlan or their own warriors in this carnival of death. According to Diego Durán's account, the lords of foreign provinces and cities dispersed full of "temor y espanto," dread and fear.

I provide this ample description of just one of the eighteen ceremonies focused by human sacrifice carried out in the Aztec capital because it shows us both the sophistication of these performances and the cosmological conviction that performing sacrifices in this way creates an ideal battlefield inside the city where Aztecs were completely triumphant and revitalized city and cosmos. To do this, the Aztecs created a theater where a living warrior god was ritually dismembered so that his highly potent skin and blood could be seen, touched, and smelled throughout the neighborhoods where the next generation of warriors were excited into war games and visuall battles, intimidate our enemy rulers in public sacrifices (debt paycity, we win all battles, intimidate our enent generation of warnents to gods), and distribute supernatural power to the next generation of warriors wholearn the Aztec way.

Historians have been able to show that as Mesoamerican states grew more complex, their rulers used larger scale human sacrifices as a method to expand their plex, their rulers ather in larger tributary payments. We now know that between 1250 domains and conquest were used as a way for men to fulfill their holy mission and 1521 warpetuate the existence of the world through human sacrifice. Aztec armies to pere of their allies carried out ambitious military campaigns from which they returned victorious with numerous prisoners for display and killing in large sacrificial festivals. The central symbol of this worldview was the Templo Mayor of Tenochtitlan and it is remarkable that as it grew in size (enlarged seven times durTenochtitlan and its 150 year existence), there were two other amplifications. The numbers of human sacrifices increased and the amount of territory controlled in Mesoamerica was progressively enlarged, ensuring a tremendous growth in tributary payments to the capital and its royal families.

\section{The Moral Imperative of Human SACRifice/Debt Payment}

In my study of the human sacrificial festivals, I was impressed with the extraordinary detail the Mexica elders recited to Sahagún. Songs, tones of voices, clothing from head to toe, dance movenents, precise gestures with occasional references to emotional responses fill the reader with a sense of motion and color, complexity, and wonder. The actual moments of killing in the narratives are, while not avoided, given much less weight and focus than the preparations of the teotl ixiptla or the descriptions of the ritual treatment of the bodies, hearts, blood, and skin as they are worn, sipped, carried, tenderly prayed to, and sometimes immolated. One sensational sacrifice suggests that moral teachings were also at stake in some of the ceremonies.

In the month of Toxcatl (the dry season) a captured warrior with "no blemishes upon his body" was changed into a teotl ixiptla of the great deity Tezcatlipoca, (Lord of the Smoking Mirror). This handsomest of individuals lived for one year in "all luxuries" while being trained in music, singing, speaking, flower arranging, and walking among the populace as a deity. The first extraordinary dimension of the festival of Toxcatl was that the most physically attractive male from among a special group of captive warriors had to conform to this official description of the ideal male.

He was like something smoothed, like a tomato, like a pebble, as if sculptured

in wood; he was not curly-haired... he was not rough of forehead... he was not 
long-headed .... He was not of swollen eyelids, he was not of enlarged eyelids, he was not swollen-cheeked... he was not of downcast face; he was not flat-nosed he did not have a nose with wide nostrils; he was not concave-nosed... he was not thick-lipped, he was not gross-lipped, he was not big-lipped, he was not a stutterer, he did not speak a barbarous language. He was not buck-toothed, he was not large-toothed... His teeth were like seashells... he was not cup-eyed, he was not round-eyed; he was not tomato-eyed; he was not of pierced eye.... He was not long-handed; he was not one-handed; he was not handless; he was not fatfingered... He was not emaciated; he was not fat; he was not big-bellied; he was not of protruding navel; he was not of hatchet shaped buttocks....For him who was thus, who had no flaw, who had no (bodily) defects, who had no blemish, who had no mark,... there was taken the greatest care that he be taught to blow the flute, that he be able to play his whistle; and that at the same time he hold all his flowers and his smoking tube. (ibid.: 71)

Tezcatlipoca was escorted throughout the city for nearly a year, greeted as a living god, enjoying luxuries even while in training in Aztec arts. He was eventually given four female companions, themselves teotl ixiptla, for sexual coupling during the last month of his existence. The elders, who had lived during these ceremonies, said of this hieros gamos, "For only twenty days he lived lying with the women, that he lived married to them." The symbolism of this ceremonial coupling is powerful as each of these wives was also a teotl ixiptla representing the goddesses of love, corn, salt, and water. The five of them, representing the five-part universe (four quarters and the center), sang and danced in public and distributed food and gifts to people at specific locations.

It was reported that at the place of his death on the outskirts of the city, "he ascended by himself, he went up of his own free will, to where he was to die." As he ascended the temple, he broke his flutes and whistles on the steps. Then the scene speeded up as the offering priests seized him, "threw him upon his back on the sacrificial stone: then cut open his breast, he took his heart from him, he also raised it in dedication to the sun" (ibid.: 71). The ixiptla's body was carefully lowered from the temple and his head severed from his body, emptied of its contents, and eventually hung on the public skull rack.

Then, according to Sahagún's informants, this journey from imprisonment to lavish deification to sexual extravagance to death on the stone led to a pronouncement of human destiny, a kind of moral understanding that humans needed to realize and follow. The ceremony reaches its climax and then the code of meaning.

And this betokened our life on earth. For he who rejoiced, who possessed riches, who sought, who esteemed our lord's sweetness, his fragrance-richness, prosperity-thus ended in great misery. Indeed it was said: "No one on earth went exhausting happiness, riches, wealth." (ibid.: 71)

Tezcatlipoca had another name which was the "Enemy on Both Sides," and his performative scenario warns everyone from top to bottom and along all pathways in the city, who certainly watched him with the knowing eyes of what was in store for him, namely that the correct death of the male warrior, even of those who live in the highest potency and privilege, is the misery of the sacrificial death, the ideal death.

\section{WOMEN IN SACRIFICE}

I. Inga Clendinnen has shown so well, this warrior ideal saturated the lives As women even as they created distinctive ways of living, caring, and dying of women en 1995). The most challenging accounts of Aztec human sacrifice to (Clendinnen those involving women and children, which took place during a numread are titual months. Space requires that I simply make the following point. Even ber of ritual "debt payments" were focused on the crucial need for seasonal fertility of plants, the intrusion of the warrior imperative of death and dismemberment ity of the performative scenario of regeneration. The itinerary of the festival of Theo iman (Mother of the Gods) moves a female teenager, under the control of Teteo imaste priestesses, from a marketplace to Moctezuma's bedchamber to the sacrifemale priestesses, from a marketplace to Moctezuma's bedchamber to the sacrifor four days amid mock public fights by groups of women-physicians, pleasure for four days alder women. The purpose was "to banish her sorrow," keep her merry and laughing for it was believed that many jaguar warriors would die in war and many women would die in childbirth if she wept in knowledge of her sacrifice. After spreading her corn seeds in an act of magical fertility, she is taken to the royal palace and told by her women handlers, "My dear daughter, at last the ruler Moctezuma will sleep with thee. Be happy... they did not tell her of her death."

Once the ruler has inserted his potency into her and drawn her deified power nto his, she is taken by the women and soon dressed for the kill. Once sacrificed, her body is skinned and worn by a male priest who displays himself before the community. Finally, a piece of the skin is taken by members of a warrior society out to the edge of the empire where it is used to taunt enemies into conflict.

\section{CONCLUSION}

In this chapter, I have indulged the Aztec records of human sacrifice because of the pressing need for us to confront these practices to learn what they tell us about human cultures in the past and perhaps our own violent ritual actions today. The Mesoamerican religious traditions did not only seek substitutes for human "debt payments" or sublimate in rituals their aggressive drives toward humans in ways that eliminated human sacrifice, as many other peoples did. Yet when the European Christians, who self-righteously claimed to have substituted symbolic violence onto one man, i.e. Jesus, instead of killing the many, arrived in Mesoamerica, they raped, killed, and injured more natives in two years than the Aztecs had sacrificed in ten. One question this raises is, where does the violence toward humans actually go once human sacrifices are given up for the fire sacrifices of animals? While we may all proclaim that we are certainly opposed to human sacrifices, the variety of ways that humans in all corners of the globe invent new forms of torture, massacre, 
and human sacrifice leads us to question, so what if official rituals of human sacrifice were replaced in Christian, Hindu, and Chinese traditions? Did that change have any significant impact in the lessening of human violence toward other humans in ritual or other ways? Or is the real change simply in the hopeful stories and theologies we tell each other about ourselves, our cultures, and our hopes for humanity? Do these inspiring stories actually lead to less violent societies?

The contemporary reader of Bernardino de Sahagún's detailed descriptions, supplied by Aztecs who saw and participated in the many "debt payment" ceremonies, will be amazed by how much they tell us about Aztec humanity beyond the norms of Mexica warfare. Many levels of Aztec existence are revealed in exquisite detail-the monumental city in its color and sound, the dancing techniques, the complex rhetoric and philosophy of the nobles, the clowns, the gender relations of teenagers joking about sex and affection, the diversity of clothes among the women whose singing voices travel through the rituals. The intense crescendo leading to and then beyond the thrust of the ceremonial knives takes us back to those silent burials of men and women found by Sugiyama in the city named the "Place Where the Gods Were Born." Looking into these festivals and tombs from the sway of the terrorisms and performances of extreme acts of devotions of our own time, we are forced to wonder about our own rituals and to what they might give birth.

\section{BIBLIOGRAPHY}

Bloch, Maurice. Prey into Hunter: The Politics of Religious Experience. Cambridge, UK: Cambridge University Press, 1992.

Burkert, Walter. Homo Necans: The Anthropology of Ancient Greek Sacrificial Ritual and Myth. Berkeley: University of California Press, 1983.

Campbell, R. B. Blood, Flesh and Bones: Kinship and Violence in the Social Economy of the Late Shang. Department of Anthropology, (unpublished PhD dissertation) Cambridge, MA, 2007.

Carrasco, David. City of Sacrifice. Boston: Beacon Press, 1999.

Chang, K.-C. Shang Civilization. New Haven, CT: Yale University Press, 1980.

Clendinnen, Inga. Aztecs. Cambridge, UK: Cambridge University Press, 1995.

Das, Veena. "Violence and Nonviolence at the Heart of Hindu Ethics." In The Oxford Handbook of Religion and Violence, edited by Mark Juergensmeyer, Margo Kitts, and Michael Jerryson. New York: Oxford University Press, 2012.

Fiskesjö, M. "Rising from Blood Stained Fields: Royal Hunting and State Formation in Shang China," Bulletin of the Museum of Far Eastern Antiquities 73 (2003): 49-191. Geertz, Clifford. Negara: The Theatre State in Nineteenth Century Bali. Princeton,

NJ: Princeton University Press, 1981.

George, Kenneth M. Showing Signs of Violence: The Cultural Politics of a TwentiethCentury Headhunting Ritual. Berkeley: University of California Press, 1996.

Hamerton-Kelly, Robert. Violent Origins: Walter Burkert, Rene Girard, and Jonathan Z. Smith on Ritual Killing and Cultural Formation. Palo Alto, CA: Stanford University Press, 1987

Heesterman, J. C. The Broken World of Sacrifice: An Essay in Ancient Indian Ritual. Chicago: University of Chicago Press, 1993.
Henninger, J. "Sacrifice." Encyclopedia of Religion. Ed. L. Jones, vol. 12: 7997-8008. New York: Macmillan Reference, 2005.

Jay, Nancy. Throughout Your Generations Forever: Sacrifice, Religion and Patemity. Chicago: University of Chicago Press, 1992.

Jones, Lindsay (ed.). Encyclopedia of Religion. New York: Macmillan Distribution, 2005 Klein, Cecelia. "The Ideology of Autosacrifice at the Templo Mayor." In The Aztec

Templo Mayor. Ed. Elizabeth Boone, 293-395. Washington, DC: Dumbarton Oaks, 1987.

Levenson, Jon. The Death and Resurrection of the Beloved Son: The Transformation of Child Sacrifice in Judaism and Christianity. New Haven, CT: Yale University Press, 1995.

Liu, Li. "Ancestor Worship: An Archaeological Investigation of Ritual Activities in Neolithic North China." In Journal of East Asian Archaeology 2.1-2 (2000): 129-164 López Austin, Alfredo. Human Body and Ideology. Salt Lake City: University of Utah Press, 1988.

López Austin, Alfredo, and Leonardo López Luján. "Aztec Human Sacrifice." In The Aztec World. Eds. Brumfiel, Elizabeth M., and Gary M. Feinmann, 137-152. Chicago: Field Museum of Natural History, 2008.

López Luján, Leonardo, and Guilhem Olivier. El sacrificio humano en la tradición religiosa mesoamericana. Mexico City: Instituto Nacional de Antropología e Historia, Coordinacíon Nacional de Arqueología, 2010.

Mack, Burton. "Introduction: Religion and Ritual." In Violent Origins: Walter Burkert, Rene Girard, and Jonathan Z. Smith on Ritual Killing and Cultural Formation, 1-70. Palo Alto, CA: Stanford University Press, 1987.

Monroe, J. C. "Continuity, Revolution or Evolution on the Slave Coast of West Africa? Royal Architecture and Political Order in Precolonial Dahomey." Joturnal of African History 48 (2007): 349-373.

Rosaldo, Renato. Ilongot Headhunting, 1883-1974: A Study in Society and History. Palo Alto, CA: Stanford University Press, 1980.

Sahagún, Bernardino de. The Florentine Codex: General History of the Things of New Spain, 12 volumes. Trans. Arthur J. O. Anderson and Charles E. Dibble. Salt Lake City: University of Utah Press, 2002 [1957-1982].

Sugiyama, Saburō. Human Sacrifice, Militarism, and Rulership: Materialization of State Ideology at the Feathered Serpent Pyramid, Teotihuacan. Cambridge, UK: Cambridge University Press, 2005.

Yuan Jing and R. K. Flad. "New Zooarchaeological Evidence for Changes in Shang Dynasty Animal Sacrifice." In Journal of Anthropological Archaeology 24.3 (2005): 252-270. 